\title{
Histopathological Spikelet Changes Produced by Fusarium graminearum in Susceptible and Resistant Wheat Cultivars
}

Karina F. Ribichich, Morfología Vegetal, Fac. de Cs. Agrarias-UNL; Silvia E. Lopez, Micología/Fitopatología, Dep. de Cs. Biológicas, FCEyN-UBA; and Abelardo C. Vegetti, Morfología Vegetal, Fac. de Cs. Agrarias-UNL, Kreder 2805 (3080) Esperanza, Santa Fe, Argentina

\begin{abstract}
Ribichich, K. F., Lopez, S. E., and Vegetti, A. C. 2000. Histopathological spikelet changes produced by Fusarium graminearum in susceptible and resistant wheat cultivars. Plant Dis. 84:794802 .

Scab is an important disease of wheat throughout the world. Fusarium graminearum is the species most frequently isolated in Argentina. Histopathological modifications observed in Pro INTA Oasis (a susceptible Argentine cultivar) and in Sumai 3 (a resistant Chinese cultivar) from the time of inoculation, at the spike emergence stage, until major disease expression (10.5 days postinoculation in the susceptible cultivar) are described. Both cultivars showed a horizontal progression of disease, from anthers to glumes, and a vertical progression, from anthers to rachis. Chlorenchyma was the most damaged tissue, with progressive chlorosis and necrosis. Walls of mesophyll, parenchyma, and epidermal cells around the lesions became thicker, particularly in the resistant cultivar. Vessels and sieve tubes were occluded, particularly the former in the susceptible cultivar and the latter in the resistant cultivar. Possible relationships between tissue changes generated during disease progression and known resistance mechanisms are discussed.
\end{abstract}

Additional keywords: comparative anatomy, fungi, Fusarium head blight, histology, histochemistry, plant-pathogen interaction

Scab, or Fusarium head blight, is an important disease of wheat (Triticum aestivum) that reduces yield and quality of grain $(7,20)$. The disease is important where wet and warm weather coincide with the heading or flowering stage $(2,12,13,25)$. In North and South America, Fusarium graminearum Schwabe (perfect stage Gibberella zeae (Schwein.) Petch) is the main pathogen associated with Fusarium head blight (5-7).

Wheat is generally most susceptible to head blight at the flowering stage, when the fungus invades extruded anthers (23). The fungus penetrates directly through natural openings (stomata) of glumes, lemmas, paleas, or the rachilla $(3,10,11,15)$. Some cultivars appear to be more susceptible after anthesis $(1,2)$. Resistance to primary infection is referred to as type I resistance and resistance to spread of the fungus within the spike is referred to as type II resistance $(19,21)$.

Morphological characteristics associated with head blight resistance (particularly type I resistance) have been evaluated

Corresponding author: K. F. Ribichich

E-mail: kribi@unl.edu.ar

Accepted for publication 22 March 2000.

Publication no. D-2000-0518-01R

(c) 2000 The American Phytopathological Society
$(14,15)$ using cultivars with less resistance than possessed by Sumai 3. Both studies compared different characters with dissimilar results. Anatomical differences associated with type II resistance among wheat cultivars have not been found (19).

The increase of physical barriers (24) and accumulation of compounds such as phenols and triticens, compounds toxic to Fusarium graminearum (21), have been implicated in resistance. The disease causes tissue alterations in chlorenchyma and other tissues $(10,11)$.

We studied the progressive infection of anthers, floral bracts, rachilla, and rachis of a susceptible and a resistant wheat cultivar, focusing on histological changes produced as a consequence of infection. We attempted to detect histological differences between infected cultivars that differed greatly in resistance to Fusarium head blight.

\section{MATERIALS AND METHODS}

Plant material. We compared the reaction of susceptible spring wheat cultivar Pro INTA Oasis with resistant spring wheat cultivar Sumai 3. Wheat was grown in a greenhouse in Esperanza, Santa Fe, Argentina (latitude $31^{\circ} 21^{\prime} 49^{\prime \prime}$ and longitude $\left.61^{\circ} 08^{\prime} 41^{\prime \prime}\right)$ from July to October, which corresponds to the normal wheat production season in the field. Temperature was reduced and relative humidity was maintained at desired levels using expanded polyurethane plates on the sides of the greenhouse, from 09:00 to 19:00 hours every day, and were monitored with a meteorological station (Davis Instruments, Inc., Hayward, CA). Ranges of temperature and relative humidity were $22.8 \pm$ $8.1^{\circ} \mathrm{C}$ and $76.2 \pm 12.4 \%$, respectively. Wheat seed of the two cultivars were sown in four rows in plots of 1.40 by $0.60 \mathrm{~m}$, assigned at random.

Fungal material and inoculum. $F$. graminearum was isolated from a single wheat spike in 1992 and stored in wheat grains at $4^{\circ} \mathrm{C}$. The fungus was cultured on Dichloran-Glycerol (DG-18) medium (8) without dichloran. After 7 days, small pieces of growing colonies were transferred to Spezieller nährstoffarmer agar (SNA) medium (8) with filter paper to induce production of macroconidia. Monosporic strains were isolated from pionnotes produced in the plates after 12 days of growth. A mixture of macroconidia from monosporic and polysporic colonies was used as inoculum.

Inoculation and sampling. For inoculation, groups of 20 to 25 wheat spikes at the spike emergence stage (growth stage 58 to 59 on Zadoks scale) were sprayed with 4 $\mathrm{ml}$ of a suspension that contained $4.5 \times 10^{4}$ macroconidia/ml of sterile distilled water. The same number of spikes were sprayed with sterile distilled water as controls. Sprayed spikes were covered with a paper bag and a plastic bag (26) for $66 \mathrm{~h}$ to maintain at least $90 \%$ relative humidity.

First symptoms appeared at a different time in each cultivar; thus, two sampling schedules were used. Samples from Pro INTA Oasis were collected at 18 and $30 \mathrm{~h}$ and $6,7.5,9$, and 10.5 days postinoculation (dpi). Samples from Sumai 3 were collected at 6 and $18 \mathrm{~h}$ and 11,14 , and $20 \mathrm{dpi}$. Symptoms were fully expressed by the last sampling time in both cases. In all, 6 to 14 spikes were harvested from each cultivar at each time.

Anatomical studies. Spikes were fixed with a formalin-aceto-alcohol solution (FAA; formaldehyde, 3.7\% [vol/vol]; acetic acid, $5 \%$ [vol/vol]; and ethanol $96^{\circ} \mathrm{C}$, $50 \%$ [vol/vol]). One middle spikelet, including the subtending section of rachis, was collected from each of three spikes and embedded in paraffin following dehydration in an alcohol series (4). Transverse and longitudinal, 8 - $\mu$ m-thick sections were obtained from the rachis, base, and middle 
part of each spikelet. These were stained with safranin-fast-green and mounted with synthetic Canada balsam.

Histochemical studies. Waxes and fats were tested with Sudan IV $(4,12)$, pectates with Ruthenium Red (4), callose with aniline blue followed by epifluorescence observation (9), cellulose by calcofluor $\mathrm{R} /$ buffer phosphate $1 \mathrm{M}, \mathrm{pH} 8$, plus epifluorescence (18), and lignin by epifluorescence observation and by phloroglucinol-chloride test (16).

Evaluation. Incidence $(\mathrm{I}=$ percentage of diseased spikes) and severity ( $\mathrm{S}=$ average percentage of diseased spikelets per spike) were calculated from observations of 12 to 21 spikes on each cultivar at each sampling time. Factorial analysis (22) was performed on subplot means for disease severity values. Simple effects and interactions between factors (cultivars and time after inoculation) were evaluated, and mean separation was based on nonplanned multiple comparisons (Procedures of Tukey-Kramer, $\mathrm{T}^{\prime}$, and GT2).

\section{RESULTS}

Incidence and severity. Pro INTA Oasis and Sumai 3 differed in the time of appearance of symptoms and in subsequent disease development. Maximum expression of symptoms on the susceptible cultivar (10.5 dpi) was recorded approximately at the same time as the beginning of symptom expression on the resistant cultivar (one diseased spikelet from one spike at $11 \mathrm{dpi})$. The final values of $\mathrm{I}$ and $\mathrm{S}$ for each cultivar were 85.7 and $58.2 \pm 22.4$ for Pro INTA Oasis, respectively, and 55.6 and $12.1 \pm 7.8$ for Sumai 3, respectively. We used only spikes with $\mathrm{S} \geq 50 \%$ of Pro INTA Oasis (72\% of infected spikes) and spikes with $\mathrm{S} \geq 10 \%$ of Sumai 3 (64\% of infected spikes) for the histological studies. The other spikes showed infection later on, possibly because of secondary inoculum. The difference in severity between cultivars was significant $(F=30.9 ; D F=1 ; P<$ 0.01). Furthermore, severity increased significantly over time for Pro INTA Oasis $(F=9.6 ; D F=3 ; P<0.01)$, but not for Sumai $3(F=0.9 ; D F=2 ; P>0.01)$, based on simple effects analysis considering time after inoculation as a factor $(6,7.5,9$, and 10.5 days for Pro INTA Oasis and 11, 14, and 20 days for Sumai 3).

Anatomical studies. At $30 \mathrm{~h}$ after inoculation, nondehisced pollen sacs of noninoculated anthers had a completely developed endothecium and exothecium, mature pollen, and a connective with zoned parenchymatic tissue circling the central vascular bundle (Fig. 1A and B). The connective was also visible in dehiscent anthers (Fig. 1C).

In inoculated anthers (Fig. 1D) of Pro INTA Oasis, at $6 \mathrm{dpi}$, pollen grains of first and second dehiscent florets had completely collapsed. Hyphae had invaded thecae and pollen, parenchymatic tissue was compressed, but vessels were not occluded. In the third floret, predehiscent anthers had been invaded by hyphae, but the connective remained intact, while several pollen grains were broken (Fig. 1F). At 7.5 dpi, the exothecium in basal florets appeared destroyed, pollen sacs were compressed and invaded by hyphae, and pollen grains appeared completely empty (Fig. 1H).

In Sumai 3, similar changes were observed, but later: dehiscent anthers were infected by 11 dpi (Fig. 1E). Pollen grains did not collapse until 14 dpi. At this time, the exothecium was partially destroyed, but the endothecium persisted with thick walls and connective vessels without occlusion (Fig. 1G and I). At $20 \mathrm{dpi}$, all symptoms were more severe, similar to symptoms of Pro INTA Oasis at $7.5 \mathrm{dpi}$.

Glumes of noninoculated Pro INTA Oasis and Sumai 3 were anatomically similar (Fig. 2A-C). The abaxial epidermis consisted of papillae, trichomes, stomata, and medium-size, thick-walled cells, whose tangential inside face was scarcely lignified. The adaxial epidermis, with thin cell walls, was lignified only at the end of wings and lacked stomata. Sclerotic hypodermis was present under both the abaxial and adaxial epidermis. Chlorenchyma alternated with parenchyma and was associated with vascular bundles (Fig. 2C). Chloroplasts were peripheral. Unlike Pro INTA Oasis, Sumai 3 chloroplasts were grouped in cells near the abaxial face (Fig. 2C).

In infected Pro INTA Oasis, changes in chloroplast arrangement of a few chlorenchymatic cells were observed at 6 dpi (Fig. 2D). At the same time, tracheal elements of a few vascular bundles were occluded by an amorphous substance (Fig. 2D), and hyphae had invaded epidermal and subepidermal cells (Fig. 2E). At 7.5 dpi, chloroplasts were grouped in the cell center, and hyphae passed through chlorenchyma tissue and emerged by stomata (Fig. $2 \mathrm{~F}$ and G). At 9 dpi, chlorenchymatous and adaxial epidermal cells were collapsed (Fig. 2I). At $10.5 \mathrm{dpi}$, the adaxial epidermis was totally destroyed (Fig. 2J). Walls of chlorenchymatous tissue were thickened. Nonphotosynthetic parenchyma was similar to controls.

Disordered chlorenchymatic cells were observed at $11 \mathrm{dpi}$ in Sumai 3. At $14 \mathrm{dpi}$ (Fig. 2H and $\mathrm{K}$ ), nonphotosynthetic parenchyma, sclerenchyma, and phloem were colonized by hyphae. Some xylem and phloem elements were occluded by hyphae or by amorphous material. Chlorenchymatic cells were collapsed or destroyed and their walls were thickened as in Pro INTA Oasis.

Lemmas of noninoculated plants had a structural pattern similar to glumes in both cultivars. Sclerotic hypodermis was present between epidermis and parenchymatic tissue or chlorenchymatic cell groups associated with vascular bundles. The tangen- tial inner face of abaxial epidermal cells was thick, but scarcely lignified. The adaxial epidermis, with thin-walled cells, was only lignified at the end of wings. Apical florets showed lemmas progressively narrower, with wings longer and with more abundant chlorenchymatic tissue (Fig. 3B). Continuous chlorenchyma occurred in the adaxial position at the center of the lemma while, at the end of the wings, chlorenchyma groups were in the abaxial position.

Lemmas of the basal florets, which were in contact with the glumes, were infected before the glumes in both cultivars. Abundant hyphae linked both of these bracts. In Pro INTA Oasis, at $7.5 \mathrm{dpi}$, the adaxial epidermis was destroyed and chlorenchyma was collapsed and necrotic (Fig. 3A and $\mathrm{C}$ ). At the end of sampling, conidiogenic cells emerged through stomata and bore conidia. The tangential face of the abaxial epidermis was thickened (Fig. 3E). All tissues of the lemma keel were colonized and only fragments of cells remained in phloem tissue (Fig. 3E and F).

In Sumai 3, at $14 \mathrm{dpi}$, walls of the abaxial epidermis were conspicuously wider than in the epidermis of the glume and the noninoculated lemma (Fig. 3B and D). Walls of hypodermal cells were thicker than controls.

Scarce chlorenchyma surrounded vascular bundles and reached the adaxial epidermis of distal paleas (Fig. 1C). Numerous hyphae linked the adaxial epidermis of lemmas and the abaxial epidermis of infected paleas. Chlorenchyma in the palea was collapsed and disorganized and the adaxial epidermis was destroyed.

The epidermis of the rachilla consisted of small cells with trichomes and papillae. Parenchyma cells became larger toward the center. Chloroplasts were absent (Fig. 4A). The growing rachilla (Fig. 4B and C) developed a lysigenous central cavity (Fig. 4D) by disintegration of the largest central parenchymatic cells. Epidermal and subepidermal cells developed thickened walls.

In Pro INTA Oasis, at $6 \mathrm{dpi}$, walls of parenchyma cells surrounding phloem of the infected rachilla were thickened. At 7.5 dpi, xylem vessels were occluded and phloem and peripheral phloem parenchyma were distorted. At 9 dpi, phloem and some portions of subepidermal parenchyma were necrotic, hyphae could be observed in the lysigenous cavity associated with vascular bundles, and walls were thickened in surrounding xylem and parenchyma cells. Subepidermal parenchyma and vascular bundle sheaths were collapsed or partially destroyed (Fig. 4E). At 10.5 dpi, epidermal cells were collapsed and destroyed, subepidermal cells were flattened against the epidermis, adjoining walls of both tissues were discontinuously thickened, and several phloem and xylem elements were occluded or their cell walls thickened (Fig. 4G). 
In Sumai 3, at $11 \mathrm{dpi}$, cell walls of the subepidermal parenchyma layers were thickened. At 14 dpi, xylem cells also showed broadened cell walls with hyphae occupying sieve tubes and vascular bundle sheaths. Cells of subepidermal parenchyma were destroyed (Fig. 4F). At $20 \mathrm{dpi}$, adjoining walls of subepidermal and epidermal tissues were thickened and destroyed, subepidermal cells were flattened against the epidermis (as in Pro INTA Oasis tissues at $10.5 \mathrm{dpi}$ ) and some vessels were occluded (Fig. $4 \mathrm{H}$ ).

The noninoculated rachis was dorsiventrally flattened. Groups of chlorenchymatic cells were associated with stomata. There were two or three layers of sclerenchymatic cells under the abaxial epidermis and parenchyma in the center (Fig. 5B). Chlorenchyma disappeared at the node and two sectors linked by several cell layers of sclerenchyma began to differentiate: the
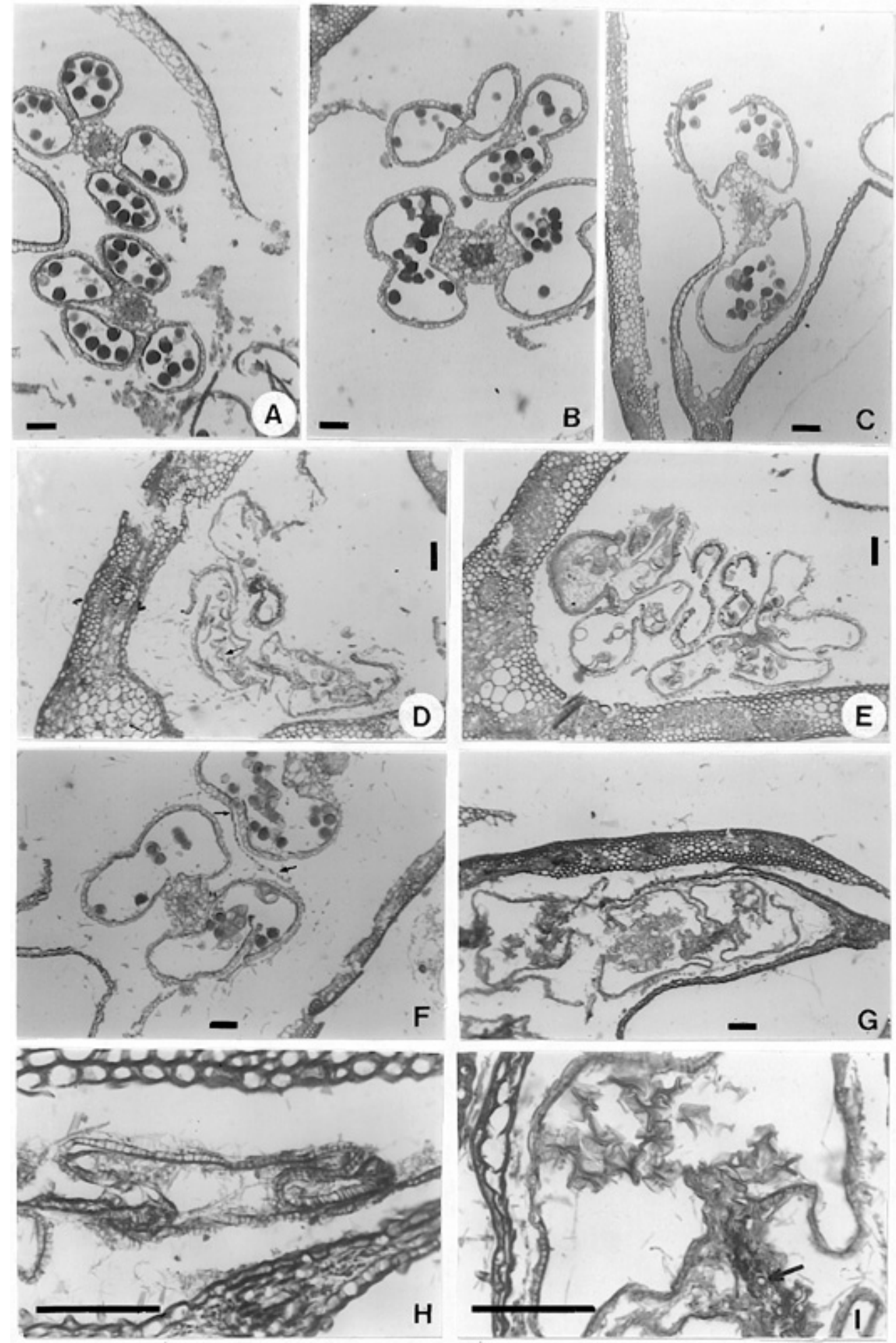

Fig. 1. Noninoculated and infected anthers of Pro INTA Oasis (A, B, D, F, H) and Sumai 3 (C, E, G, I) over time. A-C, Noninoculated at 30 h postinoculation (hpi); D-H, infected anthers; $\mathbf{D}$, first floret anthers at 6 days postinoculation (dpi), pollen grains are collapses (arrow); E, anthers at 11 dpi; $\mathbf{F}$, third floret anther at $6 \mathrm{dpi}$, hyphae invade the pollen sacs (arrows); $\mathbf{G}$, anthers at $14 \mathrm{dpi} ; \mathbf{H}$, theca at $7.5 \mathrm{dpi}$ with abundant hyphae inside; and $\mathbf{I}$, anthers at 14 dpi showing persistent endothecium wall (arrowhead), vessels without occlusion (arrow), and collapsed grains of pollen (double arrows). Bars represent $100 \mu \mathrm{m}$. 
outer, with sclerosed abaxial epidermis, and the inner, with adaxial epidermal primary walls (Fig. 5A).

In Pro INTA Oasis, at $9 \mathrm{dpi}$, xylem in the outer sector of the infected rachis was occluded. Also in this region, epidermis and subepidermis were colonized by hyphae (Fig. 5C, E, F, and I).
In Sumai 3, at 14 dpi, phloem was obstructed by hyphae and necrotic (Fig. 5D). In a proximal cross section (Fig. $5 \mathrm{~F}$ ), destruction of phloem adjoining the outer region was a generalized phenomenon and some vessels had eroded walls. Phloem of the other part of the rachis persisted with corpuscles of an amorphous substance intra and intercellularly. Epidermal and subepidermal cells were collapsed.

Where a rachilla branched from the rachis cell surrounding a central cavity, thickened walls were evident (Fig. 5H). A second kind of amorphous substance was seen in intercellular spaces surrounding parenchyma, which was stained dark red
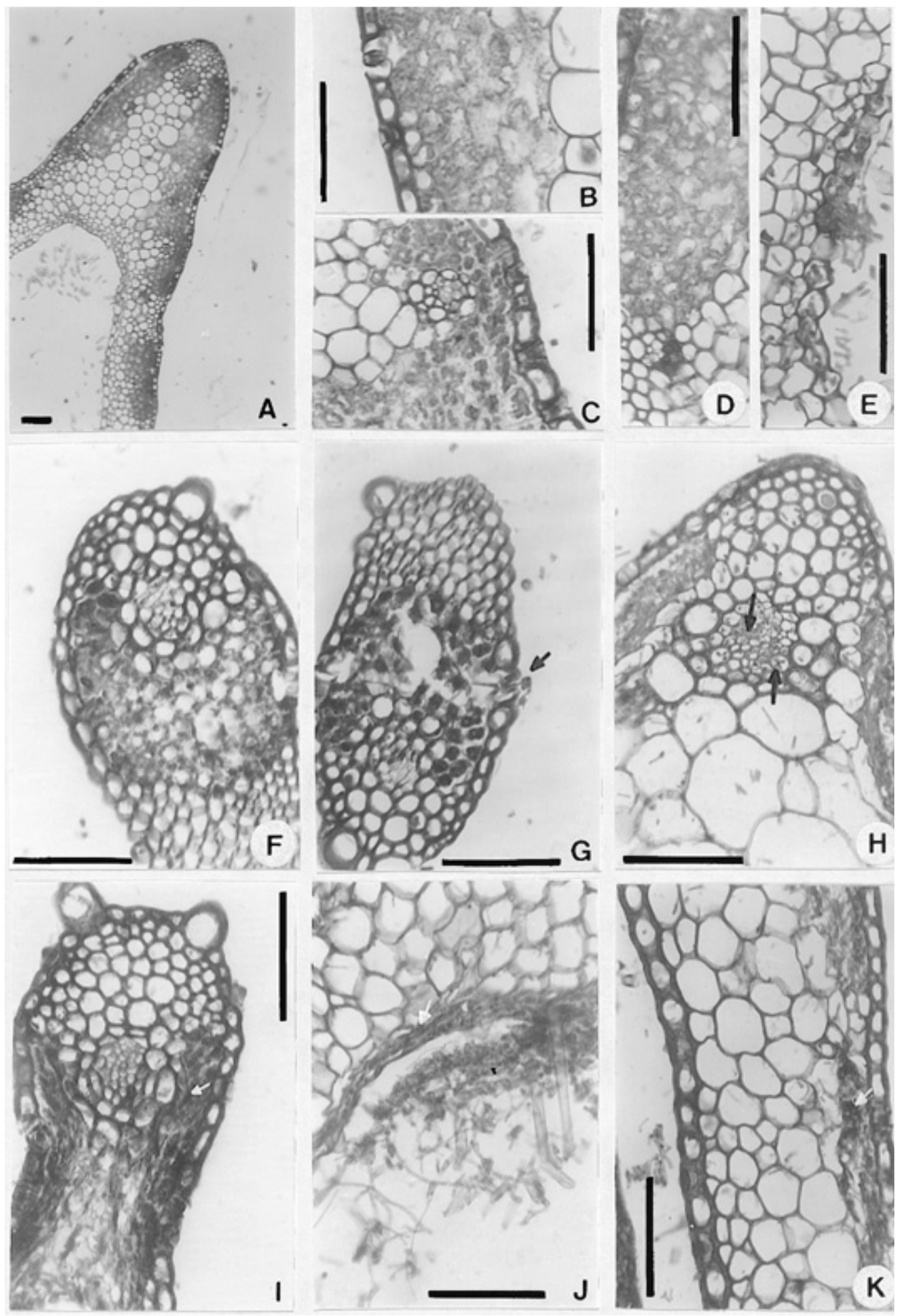

Fig. 2. Noninoculated and infected glumes of Pro INTA Oasis (A, B, D-G, I, J) and Sumai 3 (C, H, K) over time. A, B, noninoculated at 7.5 days postinoculation (dpi); C, noninoculated at $30 \mathrm{~h}$ postinoculation (hpi); D-K, infected glumes; D, E, infected glumes at 6 dpi; $\mathbf{F}$, G, infected glumes at 7.5 dpi, a hypha is crossing through glume and emerging through stoma (arrow); I, J, infected glumes at 9 and 10.5 dpi, respectively, adaxial epidermis and subepidermic cellular layers are necrotic (arrow); and $\mathbf{H}, \mathbf{K}$, infected glumes at 14 dpi, hyphae occlude phloem and also xylem elements (black arrows) chlorenchyma is necrotic, and there is cellular sclerosis (white arrows). Bars represent $100 \mu \mathrm{m}$. 
by safranin (Fig. 5J). Thin-walled epidermal tissues were collapsed.

Histochemical studies. The cuticle and exothecium of the anther were strongly stained with Sudan IV. Occlusion substances in vascular elements, intracellular and intercellular depositions, and cell walls were not stained.

Pectates of median layers showed a deep red staining with Ruthenium Red. Thickened cell walls and intracellular deposits stained slightly in decayed tissues of the rachis of Sumai 3. In controls, a similar color was observed at sclerenchymatic cells surrounding a fiber central patch (Fig. 6 A-C).

Fluorescence was not detected in the noninoculated rachis of either cultivar when stained with aniline blue. In infected rachis tissues, some occlusions of sieves elements fluoresced, more so in Sumai 3. Vessel occlusions, thickened walls and occlusion substance remained dark (Fig. 6 F-I).

Nondecayed vascular bundles stained with Calcofluor R fluoresced, but decayed vascular bundles did not. Thickened walls did not fluoresce more brightly than normal walls (Fig. 6D and E). Vascular bundles, fibers, and some sclerenchymatic cells of controls (e.g., inner layer of rachis) showed a magenta color when stained with phloroglucinol-chloride. Inner tangential walls of thick-walled epidermal cells and all epidermal walls in several lemmas had a deep red color. Some infected vascular bundles, particularly in Sumai 3, stained strongly magenta, but the sclerenchymatic layer between rachis zones, peripheral to decayed vascular bundles, stained variously pale brownish red, deep red, or homogenous magenta at the healthy area. Neither thickened walls nor intercellular and intracellular deposits reacted to phloroglucinol-chloride.

\section{DISCUSSION}

Susceptible and resistant cultivars differed in incubation period and maximum disease severity. They also differed in rate of blight development over time, indicating that Sumai 3 has type II resistance. These results agree with those of Van Ginkel et al. (27) for inheritance of resistance in the Chinese cultivar Ning 7840, a Sumai 3 descendent. In both cultivars, anthers of basal florets were the first floral parts to mature and become infected $(2,23)$, probably because they were the anthers earliest exposed to the fungus when weather favorable for infection occurred. Filaments elongated and emerged from the floret and, after self-pollination, the pressure of the growing embryo increased the angle between the lemma and palea. However, the anthers of Sumai 3 developed symptoms later than those of Pro INTA Oasis. Some barrier that arrests pathogen penetration of the first floret could be operating. This barrier would confer some degree of type I resistance. However, other variables not considered here, but that might delay penetration, cannot be excluded (e.g., percentage of anthers caught between lemmas and paleas and moisture of individual flowers enclosed by lemmas and paleas).

Although it seems clear that the anthers are the first floret parts to be infected

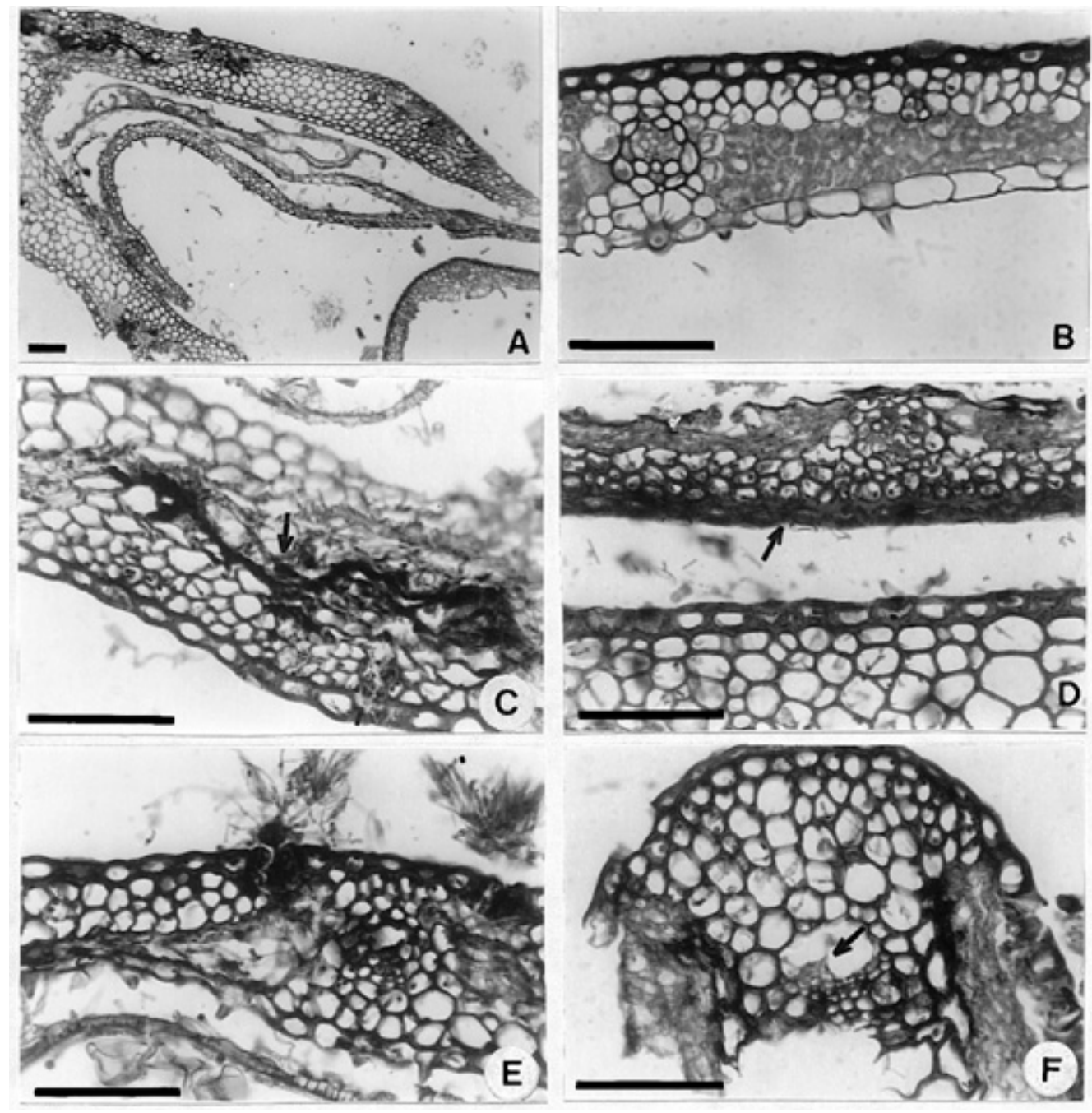

Fig. 3. Infected Lemmas of Pro INTA Oasis (A, C, E, F) and noninoculated and infected lemmas of Sumai 3 (B, D) over time. A, C, Infected lemmas at 7.5 days postinoculation (dpi), with cellular necrosis in chlorenchyma (arrow); B, D, noninoculated and infected lemmas, respectively, at 14 dpi, with the abaxial infected epidermis (arrow) thicker than the noninfected one and thicker than the infected epidermis of glume; E, F, infected lemmas at 10.5 dpi, with destroyed phloem (arrow) and scarce cellular sclerosis. Bars represent $100 \mu \mathrm{m}$. 
$(17,23)$, the fungus may be able to initiate infection on the surface of the spikelet $(3,10,11,15)$. In SEM images, we observed germinated conidia on lemmas, but not on glumes as reported elsewhere (17). However, we could not detect penetration of the lemma.

Hyphae invaded thecae through just formed stomia in dehiscent anthers and colonized the exothecium, pollen grains, and connective. The exothecium, rich in lipids, was degraded. The cytoplasm of pollen grains was free in the thecal cavities and accessible to the pathogen. Pollen grains and parenchyma of the connective collapsed. Hyphae also penetrated the lemma and palea directly, mainly through primary cell walls of adaxial epidermal cells, which collapsed and were generally destroyed.

In both cultivars, thickening of some cell walls of the abaxial epidermis was observed, which could have formed a physical barrier against pathogen invasion. Cellular collapse occurred at the same time that hyphae grew into the lemma and reached the periphery of chlorenchyma and vascular bundles. Chlorenchyma was progressively destroyed; chloroplasts were grouped in cell centers, tissue was invaded by hyphae, cells were disorganized and died, and part of the periphery of the chlorenchyma became sclerotic. Occasionally, sectors showed disorganized cells without chloroplasts. A reduction of chloroplast number has been reported previously $(10,11)$.

Cell walls of the abaxial epidermis and hypodermis of Sumai 3 became thicker
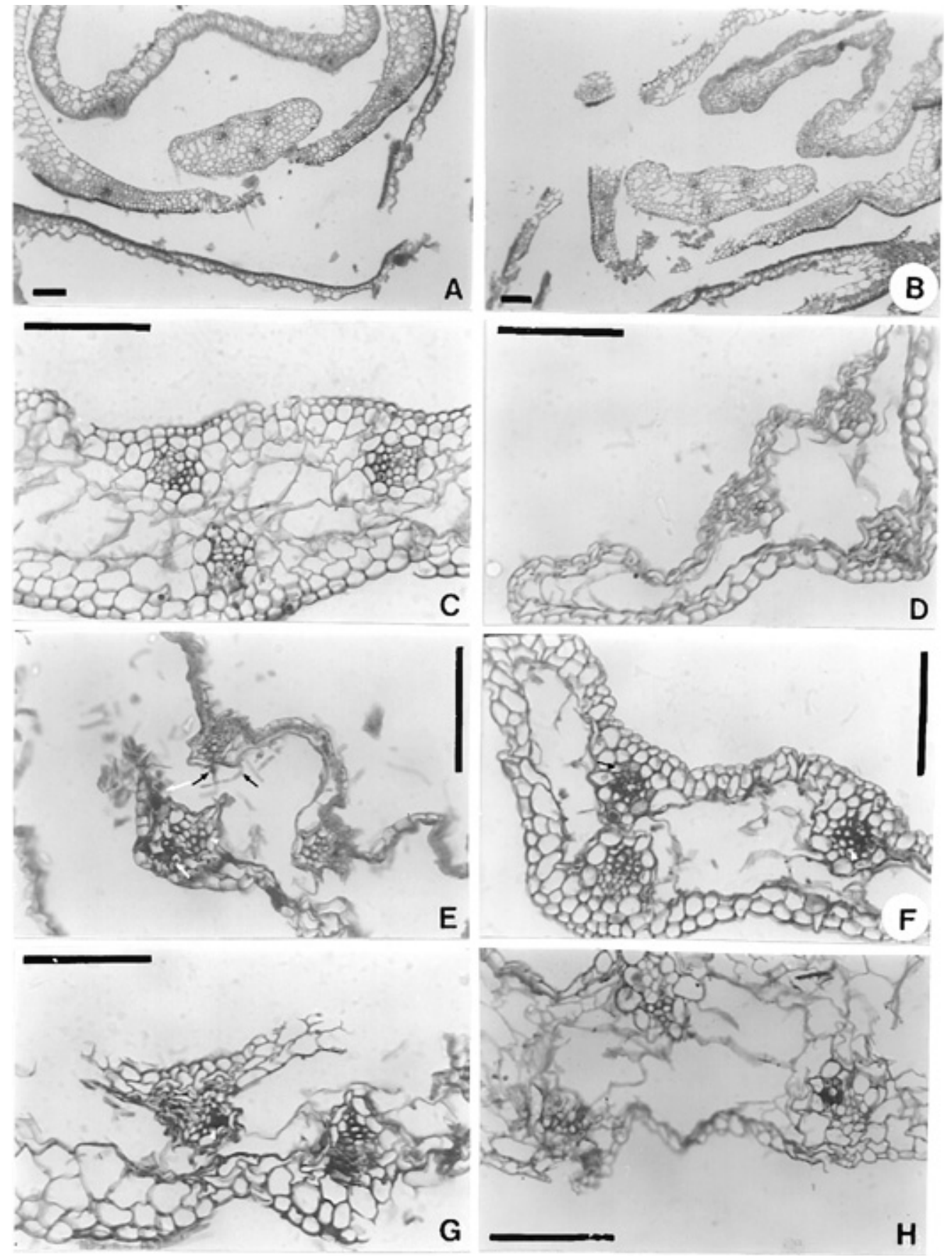

Fig. 4. Noninoculated and infected rachillas of Pro INTA Oasis (A-C, E, G) and Sumai 3 (D, F, H) over time. A, Control of 18 h postinoculation (hpi); B, $\mathbf{C}$, control of $30 \mathrm{hpi}$; D, control of 14 days postinoculation (dpi); E, G, infected rachillas 9 and 10.5 dpi, respectively, phloem and parenchyma are necrotic (white arrows in $\mathbf{E}$ ), hyphae are associated with vascular bundles (arrows in $\mathbf{E}$ ), and xylem walls are thickened (white arrowhead in $\mathbf{E}$ ), xylem elements are occluded (white arrowhead in $\mathbf{G}$ ); F, H, infected rachillas 14 and $20 \mathrm{dpi}$, respectively, hyphae are in vascular bundle sheaths and phloem (arrow in F) and xylem walls are thickened (white arrowhead in $\mathbf{F}$ ). Bars represent $100 \mu \mathrm{m}$. 
than in Pro INTA Oasis. This physical barrier in Sumai 3 did not prevent further invasion. It probably only delayed the advance of pathogen because lignification was almost absent. At the time the lemma was invaded, hyphae also penetrated the palea through the adaxial epidermis and colonized the scarce chlorenchyma. Hyphae advanced through two principal ways: emerging through stomata of the abaxial epidermis and colonizing spaces between the lemma and palea, or growing into vascular bundles.

By the first path, conidiogenic cells emerged through stomata and bore conidia,
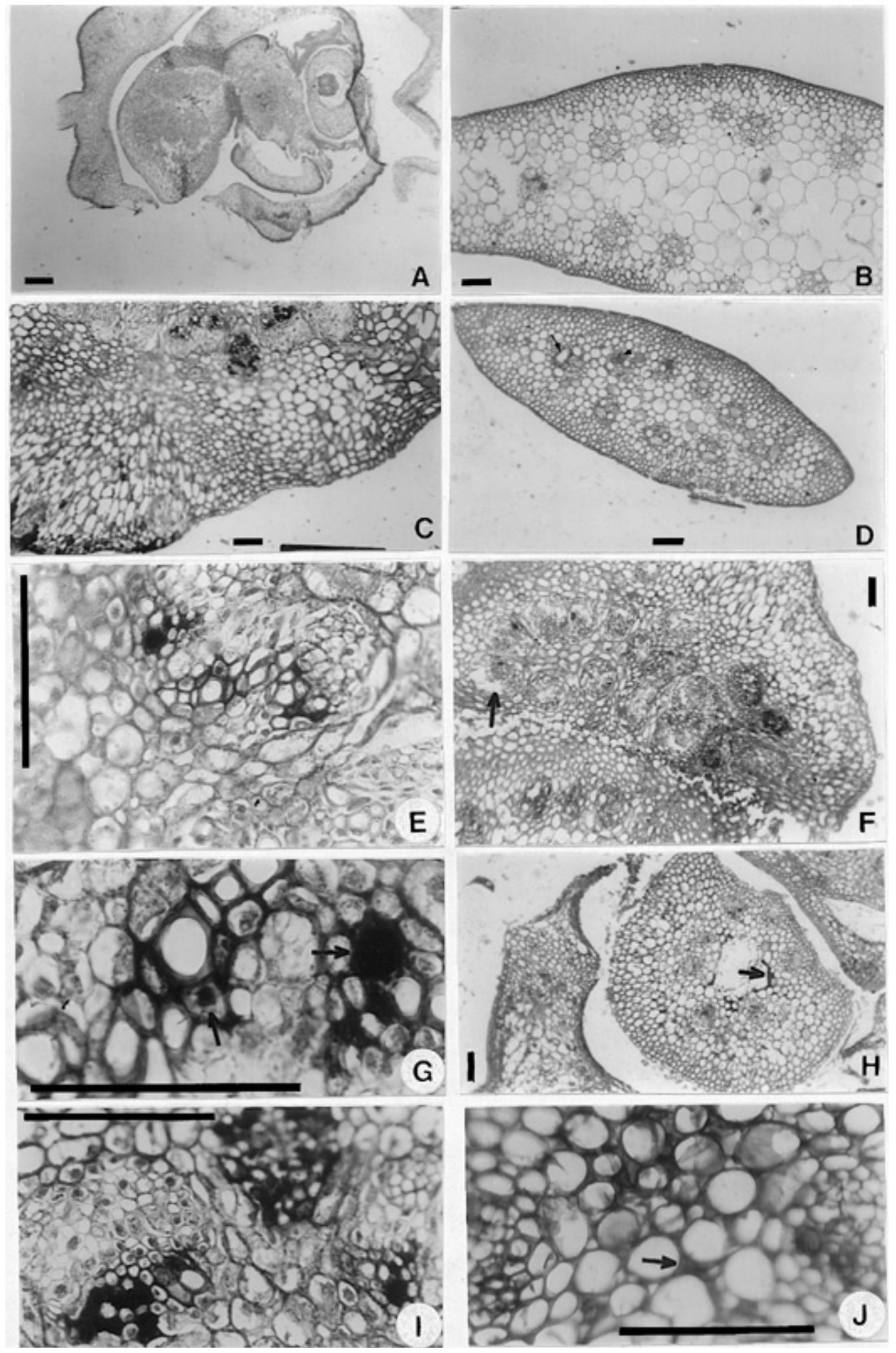

Fig. 5. Noninoculated and infected rachis of Pro INTA Oasis (A, C, E, G, I) and Sumai $3(\mathbf{B}, \mathbf{D}, \mathbf{F}, \mathbf{H}, \mathbf{J})$ over time. A, Transition zone between rachis and rachilla, thin epidermis (arrow) and thick epidermis (arrowheads) can be observed; B, noninoculated rachis; C, E, F, I, infected rachis at 9 days postinoculation (dpi); C, shows necrotic epidermis and subepidermis; $\mathbf{E}, \mathbf{G}, \mathbf{I}$, show occluded vessels and a hypha is crossing through the wall of a xylem element (arrow); D, F, H, J, infected rachis at $14 \mathrm{dpi}$, at different levels, from rachis base to spikelet base, showing occluded (arrowhead in $\mathbf{D})$ and destroyed (arrows in $\mathbf{D}, \mathbf{F}$ ) phloem, thickened walls (arrow in $\mathbf{H}$ ), and deposition of intercellular material (arrow in $\mathbf{J}$ ). Bars represent $1 \mathrm{~mm}$ in $\mathbf{A}$ and 100 $\mu \mathrm{m}$ from $\mathbf{B}$ to $\mathbf{J}$. 
resulting in orange lines, a characteristic sign of head blight, and hyphae reached neighboring glumes, causing decay similar to that in the lemma. These conidia could germinate and penetrate distal florets via anthers, but hyphae also grew over the abaxial and adaxial epidermis of these anthecia. The hyphae may also have penetrated natural openings or directly.

It is more difficult to discuss the steps of the second path. When hyphae invaded vascular bundles, histological changes were evident in both cultivars. Most phloem bundles were completely de- stroyed, principally in Sumai 3. However, xylem either remain unaltered, or some vessels were invaded by hyphae or occluded. At the same time that bracts decayed, vascular bundles of the rachilla showed the first disease symptoms. Hyphae grew into vascular bundles and ves-
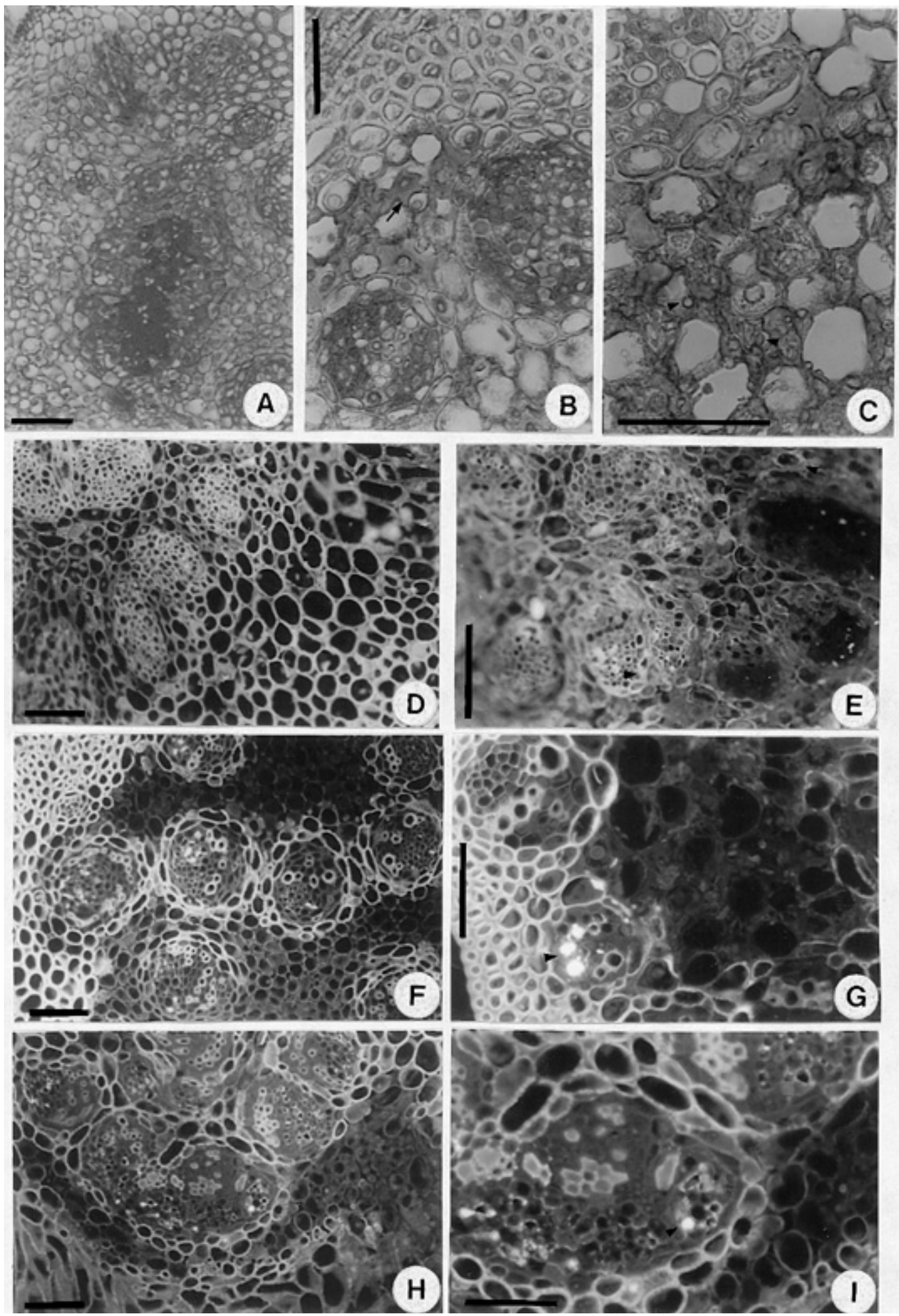

Fig. 6. Histochemical studies on rachis of Sumai 3 (A-G) and Pro INTA Oasis (H, I). A-C, With ruthenium red; A, noninoculated and B, C, infected rachis 20 days postinoculation (dpi); B and C show wall thickening (arrow in B) and intra- and intercellular depositions (arrowheads in C); D, E, with calcofluor R; D, noninoculated and E, infected rachis of $20 \mathrm{dpi}$, thickened walls do not appear brighter than normal walls (arrowhead); F-I, with aniline blue, F, noninoculated and $\mathrm{G}$, infected rachis at $30 \mathrm{~h}$ and $20 \mathrm{dpi}$, respectively, one sieve element is occluded with callose (arrowhead). Bars represent 100 $\mu \mathrm{m}$. 
sels were occluded. The walls of occluded vessels became thicker, similar to those in the parenchyma, epidermis, and subepidermis. These barriers were progressively trespassed by hyphae.

Once a spikelet was colonized, the fungus invaded adjacent spikelets. Colonization occurred in two ways, either by a horizontal path or by a vertical path. In the horizontal path, the fungus invaded anthers and bracts of contiguous florets in the first spikelet invaded, then moved through the rachis and the rachilla to the contiguous spikelet. In the vertical path, the fungus moved through vascular bundles and parenchyma to invade spikelets above and below the originally infected spikelet. Vascular bundles appear to be an avenue. These result do not agree with a previous report (17). Spikelets both distal and basal proximal to the originally infected spikelet were invaded by both pathways.

Rachis segments are shorter in Pro INTA Oasis than in Sumai 3 (K. F. Ribichich and A. C. Vegetti, unpublished data), which may promote invasion in the horizontal direction. Invasion through the inner face of the rachis could also be increased compared to invasion in Sumai 3. Colonization in the vertical direction was delayed or halted in Sumai 3. Chlorosis, necrosis, and occlusion of vascular bundles were seen in the rachis of both cultivars, but the time after inoculation when they were registered, the number of spikelets affected, and the physical barriers produced in both cultivars were different. These results do not agree with other reports on the absence of anatomical differences between susceptible and resistant infected cultivars (19).

Throughout horizontal colonization, walls of parenchyma of both cultivars thickened as a barrier, and tissues produced inter- and intracellular deposition of amorphous material. Walls of parenchyma cells surrounding vascular bundles also became thicker, while hyphae were seen in vessels and sieve-elements.

In Pro INTA Oasis, there was no defensive reaction when phloem was colonized or destroyed. Vessels occluded by hyphae or an amorphous substance were not an effective barrier to advance of the pathogen. In Sumai 3, a stronger and more localized reaction to infection seemed to occur in the invaded tissue. A barrier seemed to delay horizontal invasion. Phloem was occluded, probably with callose, but not destroyed. During vertical invasion, phloem was destroyed by the pathogen, or the pathogen was encircled by the host, through wall thickenings and depositions of intra- or intercellular amorphous material in vascular bundles. It remains to be determined if similar reactions occur in other resistant and susceptible cultivars.

\section{ACKNOWLEDGMENTS}

We thank M. T. Villar de Galich for supplying seed of Sumai 3, a fungal strain, and several reports; CIMMYT for supplying seed of Sumai 3; A. Amsler, D. Sanchez, and J. C. Tivano for technical assistance; L. M. Rista and R. Pilatti for their suggestions; J. E. Wright for correction of the manuscript; and Consejo Nacional de Investigaciones Científicas y Técnicas, Argentina (PIA), and Universidad Nacional del Litoral (CAI+D) for financial assistance.

\section{LITERATURE CITED}

1. Andersen, A. L. 1948. The development of Gibberella zeae head blight of wheat. Phytopathology 38:595-611.

2. Bai, G., and Shaner, G. 1994. Scab of wheat: Prospects for control. Plant Dis. 78:760-766.

3. Bennett, F. T. 1931. Gibberella saubinetii (Mont) Sacc. On British cereals. II. Physiological and pathological studies. Ann. Appl. Biol. 18:158-177.

4. D'Ambrogio de Argueso, A. 1986. Manual de Técnicas en Histología Vegetal. Editorial Hemisferio Sur, Buenos Aires, Argentina. pp. 28-33, 59-60.

5. Díaz de Ackermann, M., and Kohli, M. M. 1997. Research on Fusarium head blight of wheat in Uruguay. Abstracts in: Fusarium Head Scab: Global Status and Future Prospects. H. J. Dubin, L. Gilchrist, J. Reeves, and A. McNab, eds. CIMMYT, México, D.F., México.

6. Galich, M. T. V. de. 1997. Fusarium head blight in Argentina. Abstracts in: Fusarium Head Scab: Global Status and Future Prospects. H. J. Dubin, L. Gilchrist, J. Reeves, and A. McNab, eds. CIMMYT, México, D.F., México.

7. Gilchrist, L., Kazi, M., Rajaram, S., Vivar, H. and van Ginkel, M. 1997. CIMMYT scab Fusarium program. Abstracts in: Fusarium Head Scab: Global Status and Future Prospects. H. J. Dubin, L. Gilchrist, J. Reeves, and A. McNab, eds. CIMMYT, México, D.F., México.

8. Hocking, A. D., and Pitt, J. I. 1980. Pages 611 in: An Illustrated Manual on Identification of Some Seed-Borne Aspergilli, Fusaria, Penicillia and Their Mycotoxins. 1st ed. K. Singh, J. C. Frisvald, U. Thrane, and S. B. Mathur, eds. Danish Government Institute of Seed Pathology for Developing Countries, Hellerup, Denmark.

9. Hood, M. E., and Shew, H. D. 1996. Applications of $\mathrm{KOH}$-aniline blue fluorescence in the study of plant-fungal interactions. Phytopathology 86:704-708.

10. Ireta-Moreno, J. 1987. Estudio histopatológico de la espiga del trigo durante la penetración de $F$. graminearum. Pages 50-57 in: Estimaciones de pérdidas de trigo (Triticum sp. L.) causadas por la roña (Fusarium graminearum Schw.). Tesis de Post-Grado, Chapingo, México.
11. Ireta-Moreno, J., and Bekele, G. T. 1987. Histopatología de la penetración de Fusarium graminearum Schw en trigo. Pages 85-89 in: Taller sobre la Fusariosis de la Espiga en America del Sur. M. M. Kohli, ed. CIMMYT, Encarnación del Paraguay, Paraguay.

12. Kohli, M. M. 1987. Análisis de la fusariosis del trigo en el cono sur. Pages 1-6 in: Taller sobre la Fusariosis de la Espiga en América del Sur. M. M. Kohli, ed. CIMMYT, Encarnación del Paraguay, Paraguay.

13. Mielke, H. 1988. Untersuchungen ueber Fusarium culmorum (W. G. Sm.) Sacc. als Fuss- und AEhrenkrankheitserreger beim Weizen. Mitt. Biol. Bundesanst. Land. Forstwirtsch. Berlin-Dahlem 238:1-101.

14. Nakacawa, M. 1960. Studies on the resistance of what varieties to Gibberella saubinetti regarding their genetical characters and environmental factors. Bull. First Agron. Div. Tokai-Kinki Natl. Agric. Exp. Stn. No. 7.

15. Nisikado, Y. 1958. Studies on the wheat scab caused by Gibberella zeae (Schw.) Petch. and its control. Ohara Institute of Agriculture Biology, Okayama University, Japan.

16. Ougham, H. J., Latipova, G., and Valentine, J. 1996. Morphological and biochemical characterization of spikelet development in naked oats (Avena sativa). New Phytol. 134:5-12.

17. Pugh, G. W., Johann, H., and Dickson, J. G. 1933. Factors affecting infection of wheat heads by Gibberella Saubinetii. J. Agric. Res. 46:771-797.

18. Romero, A. I., and Minter, D. W. 1988. Fluorescence microscopy: an aid to the elucidation of ascomycete structures. Trans. Br. Mycol. Soc. 90:457-470.

19. Schroeder, H. W., and Christensen, J. J. 1963. Factors affecting resistance of wheat to scab caused by Gibberella zeae. Phytopathology 53:831-838.

20. Snijders, C. H. A. 1990. Fusarium head blight and mycotoxin contamination of wheat, a review. Neth. J. Plant Pathol. 96:187-198.

21. Spendley, P. J., and Ride, J. P. 1984. Fungitoxic effects of two alak-2,4-dienals, $\mathrm{x}$ - and B-triticene, isolated from wheat. Trans. Br. Mycol. Soc. 82:283-288.

22. Steel, R. G. D., and Torrie, J. H. 1985. Bioestadística: Principios y Procedimientos. McGraw-Hill Latinoamericana, México, D.F., México. pp. 194-211.

23. Strange, R. N., and Smith, H. 1978. Specificity of choline and betaine as stimulants of Fusarium graminearum. Trans. Br. Mycol. Soc. 70(2):187-192.

24. Stubbs, R. W., Prescott, J. M., Saari, E. E., and Dubin, H. J. 1986. Manual de metodología sobre las enfermedades de los cereales. Centro Internacional de Mejoramiento de Maíz y Trigo (CIMMYT), México.

25. Sutton, J. C. 1982. Epidemiology of wheat head blight and maize ear rot caused by Fusarium graminearum. Can. J. Plant Pathol 4:195-209.

26. Teich, A. H., and Michelutti, R. 1993. Determining resistance to wheat scab by covering field-inoculated heads with plastic bags. Cereal Res. Commun. 21:69-73.

27. Van Ginkel, M., Van Der Schaar, W., Zhuping, Y., and Rajaram, S. 1996. Inheritance of resistance to scab in two wheat cultivars from Brazil and China. Plant Dis. 80:863-867. 